\title{
Factors Affecting Loan Supply Behavior at the Sharia Business Unit of Bank Sulselbar
}

\author{
Andi Aswan ${ }^{1}$, Jusni ${ }^{2}$, Andi Ratna Sari Dewi ${ }^{3}$
}

\begin{abstract}
The study was conducted to assist the Sharia Business Unit of Bank Sulselbar in an effort to increase sharia financing portfolio. The study examines four variables (deposit funds, cash, placement, profit sharing) that affect financing volume. The data were collected from a quarterly published financial report in the period between December 2009 to June 2017 and Indonesian Statistical Report. With the use of multiple regression analysis to test the studied variables, it is found that deposit fund and GRDP affect positively and significantly to the total volume of sharia financing, whereas cash and placement with other banks negatively affect the total volume of financing with the insignificant score for placement. Interestingly, profit sharing ratio affects negatively and significantly to the total volume of sharia financing.
\end{abstract}

Keywords: Sharia Business Unit, Financing volume, Deposit Funds, Placement, Profit Sharing.

This is a research in Banking and Finance.

${ }^{1}$ Department of Management, Faculty of Economics and Business, Hasanuddin University. Jln.

Perintis Kemerdekaan KM. 10, Tamalanrea. andiaswanp@yahoo.com

${ }^{2}$ Department of Management, Faculty of Economics and Business, Hasanuddin University. Jln.

Perintis Kemerdekaan KM. 10, Tamalanrea. jusni mju@yahoo.co.id

${ }^{3}$ Department of Management, Faculty of Economics and Business, Hasanuddin University. Jln.

Perintis Kemerdekaan KM. 10, Tamalanrea. andiratna saridewi@yahoo.com 
This study was inspired to provide a help for the Sharia Business Unit of Bank Sulselbar in an effort to drive up financing distribution in South Sulawesi Province. It is known that the proportion of Islamic financing in the province is still relatively smaller than the proportion of conventional loans distributed. Currently, the amount of Islamic financing is only about $4-7 \%$ per annum of total loans disbursed by Bank Sulselbar (Bank Sulselbar, 2011 -2016). Of course, the percentage was too small when compared to the numbers of Muslim populations in South Sulawesi. This number should drive up Muslim persons to apply for Islamic loan (shariah financing) compared to take a conventional credit portfolio. Muslim persons believe that conventional loans ignore Islamic law which can be categorized as riba or usury which is unjust and prohibited. It is mentioned four different revelations in the holy books of the Qur'an such as in Q.S Al-Baqarah [2] 275 (Hashim, 2008). This is also the reinforced by the provisions of Fatwa Haram from MUI in 2003 (e.g. Suhendi, 2002 and Kusmiyati, 2007).

The study of sharia financing in Islamic banks has been studied in various countries in the world, including in Indonesia. In Indonesia, a number of researchers have examined it using various methods, variables, and categories of banks and different time period. Associated with the category of banks, a number of researchers use information of Shariah banks listed on the Indonesia Stock Exchange (Kalkarina et al, 2016). Other researchers study sharia banks operating in Indonesia (e.g. Furqaini \& Yaya, 2017; Puspitasari \& Elen, 2017; and Andraeny, 2011). There are also a number of researchers study individual bank level, for example, Bank Muamalat (Pratami \& Muharram, 2011) Bank Mandiri Syariah (Pato, 2013 and Rejeki, 2013) and Bank Syariah BNI (Susilo et al, 2012).

With respect to the method used by scholars, they generally used multivariate regression analysis (e.g Kalkarina et al, 2016 and Puspitasari \& Elen, 2017; Palupi \& Kusumawati, 2015; Furqaini \& Yaya, 2017). However, a number of researchers are also found using others methods, such as Kalkarina et al (2016) used three combinations of statistical methods, descriptive statistics, regression, and panel regression. Andraeny (2011) used Partial Least Square (PLS) and Susilo et al (2012) applied SWOT analysis that is called Strengths Weakness, Opportunities, and Threats.

On the variable level, a number of researchers focus on studying certain variables associated with the distribution of sharia financing by Islamic banks, and they do not take into account such variables as placement, GRDP, and cash. The researchers tend to discuss mostly on such variables as Capital Adequacy Ratio (CAR), NonPerforming Financing (NPF) and / or third-party funds and their effect on sharia financing (eg Furqaini \& Yaya, 2017; Andraeny, 2011; Kalkarina et al, 2016 and Puspitasari \& Elen, 2017; Pratami \& Muharram, 2011; Palupi \& Kusumawati, 2015). Other variables that are also used to test the relationship with sharia financing are equity variables (Puspitasari \& Elen, 2017 and Palupi \& Kusumawati, 2015), profit sharing (Furqaini \& Yaya, 2017 and Andraeny, 2011) and Return on Assets (ROA) (Pratami \& Muharram, 2011).

The study focuses on Sharia Business Unit of Bank Sulselbar. To best of our knowledge, there is a few researchers studied sharia business unit owned by regional development banks, but they do not discuss sharia financing. It is, for 
example, the study at Sharia Business Unit of Bank Riau (Nandar, 2010), Sharia Business Unit of Bank Central Java, Sharia Business Unit of Regional Development Banks operated within Sumatera Island (Cahyono \& Rani, 2017), and in Sharia Business Unit of Bank DIY (2017).

\section{Sharia Financing}

As an intermediary institution, banks play a role in raising funds and channeling back in the form of loans. This role is also done by sharia banks and sharia business units owned by a number of regional development banks. Different with conventional banks that promise deposit interest rates to customers for placing their funds, sharia banks pledge profit-sharing to its depositors. In relation to financing activities, sharia banks, and sharia business units also promise profit financing sharing with different shares for each financing products offered depending on the initial agreement made (Ghafar et al, 2010). Financing products offered by the Islamic banks are mudharabah and musharakah, and sell-buy financing (Huda, 2012). Mudharabah is a contract that all capitals are provided by an Islamic bank and the other parties will conduct activities to manage the funds (Mawaddah \& Hidayat, 2012). This mudharabah is sometimes called profit sharing contract (Ghafar et al, 2010).

Differently, Musharakah often called partnership contract is a joint enterprise to conduct some businesses in which all partner two or more share the profit according to specific agree ratio, while loss is shared according to their contribution (Usamani, 1999; Osmani \& Abdullah, 2010; and Arshad \& Ismail, 2010; Ghafar et al, 2010).

Associated with the measurement of sharia financing performance, there are two measurements that are often used by scholars. Measurement based on the ratio of sharia financing disbursement that is called Financing to Deposit Ratio (FDR) (Ika \& Abdullah, 2011; Masruki et al, 2011; and Seibel, 2008). This is the ratio of total sharia financing divided by a number of Islamic deposit funds collected from societies. This ratio is most often used to measure performance (Setiawan \& Putri, 2013), and it is one of the tools used by the Financial Services Authority to monitor sharia bank or sharia business unit. In addition to FDR, sharia financing performance can also be measured by volume of total sharia financing. This term is only used by a few scholars.

Sharia financing has been reviewed by a number of literature and they found that it is influenced by a strong relationship with sharia deposit funds, profit sharing financing ratios, placements, cash, and GRDP.

\section{Sharia Deposit Funds}

Like conventional banks, sharia banks and sharia business units also collect money from societies called as sharia depositor funds (Ariff, 1998). The products consist of demand deposits, savings deposits, and time deposits. The products follow Islamic principle. Deposit products are demand deposit of wadiah and mudarabah, saving a deposit of wadiah and mudarabah, and time deposit of mudarabah. 
This sharia deposit funds are also used as a buffer to support sharia financing activities (Sun et al, 2014 and Kamil et al, 2013). This is a main source of funds in supporting any sharia financing decision made by sharia banks and sharia business units (Hadad et al, 2012). Other sources could also support for financing, but sharia deposit funds are preferred as they are easily collected and relatively cheaper than other sources of funding, like placement and borrowing funds. That is why, it can be said that there is a tight relationship between Islamic deposit funds and the volume of sharia financing as amplified by some literature (e.g. Hadad et al, 2012 and Kamil et al, 2013).

$\mathrm{H1}$ : Amount of sharia deposit funds affects positively and significantly the total volume of sharia financing.

\section{Profit Sharing Financing}

In addition to Islamic deposit funds, profit sharing financing ratios could possibly affect shariah financing channeling (Basher et al, 2015; Kamil et al., 2013). Profit sharing financing includes profit sharing financing obtained from financing activities of mudarabah and musharakah. This study applies profit sharing financing ratio which is the sum of profit sharing from financing activities of mudarabah and musyrakah divided by the total amount of financing channeled by Sharia Business Unit of Bank Sulselbar in one year.

Theoretically, sharia financing activities have increased when the ratio of profit sharing financing increases. On the other words, Islamic banks will put more effort to push financing activities when they experienced high profit sharing from financing activities in the previous period (Kamil et al, 2013 and Zaher \& Hasan, 2001). In contrast, financing activities may drive down when the banks experienced a low in profit sharing financing ratios. These findings are also the same with conventional banks (Sudirman, 2003). It is logically accepted that financing activities provide a possible risk than other option investment activities such as placement with other banks (Kamil et al, 2013).

$\mathrm{H} 2$ : Profit sharing financing ratio from previous years affects positively and significantly the total volume of sharia financing

\section{Placement with banks and other institutions}

Another factor that can affect the volume of sharia financing is the amount of placement on other banks. it is the inter-bank placement of deposits (Ismail, 2009 and Bacha, 2008). It is listed on the balance sheet of the asset side that is named placement with another bank (Mokhtar et al, 2006). A bank can place some of its collected funds into another bank to anticipate liquidity shortage (Ali, 2013 and Khan, 2010). When a banks keep its money on hand in form of cash, the bank has to pay saving interest to the depositors (Mokhtar et al, 2006 and Juoro, 2008). When the collected money put on other banks, the bank can earn some money and even in a certain condition, the funds can be taken immediately in the use to buffer liquidity shortage (Ali, 2013; Gupta \& Jain, 2004 and Nuswantara, 2013). So, the best decision should be made is to consider some money on hand to anticipate liquidity 
demand in short time, and putting other some money to earn saving interest that is used to pay the cost of interest to depositors (Ali, 2013).

Logically, the relationship between placement with other banks and financing is available (Gupta \& Jain, 2004 and Muda et al, 2013). When bank decided to allocate its collected funds on placement with another bank account, it affects liquidity on hand. This then influences the ability of the bank to conduct financing activities (Muda et al, 2013 and Alzalabani \& Nair, 2013). Each financing decision made, it should be supported with liquidity on hand. This relationship has been studied by some scholars.

H3: Amount of placement funds allocated with other banks affects negatively and significantly the total volume of sharia financing.

\section{Cash}

Cash is the main source of liquidity. Amount of cash on hand owned by Islamic banks may vary between one bank and another bank. This is also affected by liquidity issue that has ever been experienced by a bank (Panetto, 1996). A bank that ever experienced shortage liquidity may allocate more funds in its cash account to anticipate such matters not to be happened again (Ismail, 2011 and Mohammad, 2013). Also, If a bank can predict it fresh money needed in a day or in a certain period for liquidity buffer, the bank could allocate a few funds in cash account (Ismail, 2011 Hadad et al, 2012; and Panetto, 1996).

Amount of funds allocated in cash account by the bank affects the volume of financing (Ismail, 2011 and Hadad et al, 2012). When bank decided to allocate more funds in form of cash as a buffer to anticipate liquidity matters, the more idle funds or unproductive funds the bank has. These idle funds certainly influence the total amount of financing made by a bank. Bank policy to allocate more funds in form of cash on hand could hamper financing activities as liquidity needed for financing will be less (Singkey, 1998 and Panetto, 1996).

$\mathrm{H} 4$ : Amount of cash allocated to the cash account affects negatively and significantly the total volume of sharia financing

\section{Gross Domestic Regional Product}

Besides internal-specific condition, the external-specific condition such as economic condition reflected by Gross Domestic Product (GDP) could possible influence loan supply decision(s) made by sharia banks and sharia business units. In conventional banks, this relationship has been noted by literature (Burton et al, 2003; Dell'Ariccia and Marquez, 2003; Eickmeier et al., 2008; and Blanchard, 2003). In sharia banks, this positive relationship is also found (e.g. Hassan \& Bashir, 2003 and Naifar, 2016).

The influence of economic factors on the increase or decrease of sharia financing can be viewed from demand and supply side. The increase in economic activities means that there is an increase in productivities. The increase in productivities can continue or become more increase if sustained by the source of loan funds, one of which is through sharia financing. The reason is that the companies have limited capital resources to support the increase in production due to increased demand for 
goods and services so that they would apply for loans to support their production activities.

With respect to the supply side, an increase in economic activities will result in an increase in the profitability of the businesses and even lead to an increase of new companies. This will then drive financial institution, including Islamic banks or sharia business units to provide more sharia financing due to an increase in a number of potential customers (Abduh \& Omar, 2012). At the household level, economic activities will increase the level of income and income stability of household due to job certainty. This will then drive up numbers of banks to offer to finance to households. In sum, the higher the economic activity, the more potential customers are characterized by their ability to repay loans as well as the certainty of financing repayments. Under these conditions, banks, including sharia banks and sharia business units, are likely to provide more sharia financing in expecting to grab market potentiality.

For the purpose of the research, the study uses Gross Domestic Product (GDP) to describe the economic condition. Several studies employ economic condition as measure using various indicators such as inflation, interest and exchange rate, the balance of payment, and many others, which generally provide broad measurements (Burton et al, 2003). This study focuses a certain region in Indonesia; hence, GRDP is considered the most appropriate measurement to reflect the regional economic condition (Burton et al., 2003). we narrow down economic condition into the regional economic condition and define it as the degree of regional economic outlook in a certain area of a city or regency within a specific period of time.

H5: Output GRDP affects positively and significantly the total volume of sharia financing

\section{Methodology}

\section{a. Sample, Data, and Procedures}

The study uses quarterly time series data of the Sharia Business Unit of Bank Sulselbar from December 2009 to June 2017. In respect to bank data, they were obtained from quarterly financial published report downloaded in the Bank Sulselbar. Another data of quarterly Gross Regional Domestic Product was taken from Statistics Indonesia website, including statistical yearbook of Indonesia 2010 -2016 and Bank Indonesia, 2010 - June 2017. 
Table 1 : Descriptive Statistics for Main Variables

\begin{tabular}{|l|r|r|r|r|r|}
\hline \multicolumn{7}{|c|}{ Descriptive Statistics } \\
\hline & $\mathrm{N}$ & \multicolumn{1}{|c|}{ Minimum } & Maximum & \multicolumn{1}{c|}{ Mean } & \multicolumn{1}{c|}{ Std. Deviation } \\
\hline Cash & 31 & 1518.00 & 7239.00 & 3888.8387 & 1571.98450 \\
\hline Placement with other bank & 31 & 30440.00 & 369048.00 & 173974.8387 & 108794.45932 \\
\hline Profit Sharing Financing & 31 & .023 & .148 & .07002 & .035919 \\
\hline Deposit Funds & 31 & 40959.00 & 542134.00 & 269460.4194 & 148018.62010 \\
\hline GRDP & 31 & 23.56 & 71.25 & 52.0667 & 11.55333 \\
\hline
\end{tabular}

\section{b. Method of Data Analysis}

Before analyzing the data obtained, the data are tested outlier detection firstly and multicollinearity as well as normality residual distribution test.

On the basis of the statistical result of outlier identification, whole data evaluated do not contain an outlier. According to Rousseeuw \& Hubert (2017) when data was lied in between positive 2.5 and negative 2.5 , the data do not contain outlier values. (Rousseeuw \& Hubert, (2017). The given statistical results using SPPS version 23 to evaluate outlier using z-score test indicate that the five data studied do not exceed the minimum and maximum score to be said to have outlier data.

Tabel 2 : Z-score value for the sample

\begin{tabular}{|l|l|r|}
\hline Zscore Value & Minimum & Maximum \\
\hline Zscore (Sharia_Financing) & -1.86289 & 1.34414 \\
\hline Zscore (Placement) & -1.31932 & 1.79304 \\
\hline Zscore (Cash) & -1.50818 & 2.13117 \\
\hline Zscore (GRDP) & -2.46749 & 1.66050 \\
\hline Zscore (Profit_Sharing_Financing) & -1.31012 & 2.17597 \\
\hline Zscore (Deposit Funds) & -1.54373 & 1.84216 \\
\hline
\end{tabular}

Besides outlier detection, the data are tested for multicollinearity to avoid bias in the coefficient estimates and to specify the correct model in the given equation result. To do so, the study applies Variance Inflation Factor (VIF) and tolerance. The results indicate that the lowest tolerance score is 0.310 , while the highest is 0,874 . With respect to VIF, the highest is 3.227 and the lowest is 1.320 . Widarono (2010) explains if using VIF and tolerance method, score tolerance is not to 0 and VIF score less than 10 means that there is no multicollinearity. On the basis of the given result, it can, therefore, be said that there is no multicollinearity.

Table 3: Multicollinearity Test 


\begin{tabular}{|c|c|c|c|c|c|c|c|}
\hline & & \multicolumn{2}{|c|}{ Unstandardized Coefficients } & \multirow[b]{2}{*}{$\mathrm{t}$} & \multirow[b]{2}{*}{ Sig. } & \multicolumn{2}{|c|}{ Collinearity Statistics } \\
\hline \multicolumn{2}{|c|}{ Model } & B & Std. Error & & & Tolerance & VIF \\
\hline \multirow[t]{6}{*}{1} & (Constant) & 191865.860 & 108342.670 & 1.771 & .089 & & \\
\hline & Placement & -.301 & .314 & -.960 & .346 & .383 & 2.613 \\
\hline & Cash & -47.784 & 18.539 & -2.578 & .016 & .525 & 1.906 \\
\hline & GRDP & 4446.412 & 2099.186 & 2.118 & .044 & .758 & 1.320 \\
\hline & Profit_Sharing_Financing & -1329839.361 & 628788.888 & -2.115 & .045 & .874 & 1.145 \\
\hline & Deposit_Funds & 1.394 & .256 & 5.440 & .000 & .310 & 3.227 \\
\hline
\end{tabular}

With respect to residual distribution, the study also undertakes normality distribution test using the P-P plot. Scholars noted that normal distribution is not needed when data have large samples $(>30)$ since the sampling distribution tend to be normal (Ghasemi \& Zahediasi, 2012; and Pallant, 2007). However, to validity certainty of data, the collected data test their normality using the P-P plot. This is one of reliable normality distribution test counting on visual judgment (Ghasemi \& Zahediasl, 2012 and Altman \& Bland, 1995). From the test result using Probability Probability plot or called P-P plot of Standardized Residual regression, it can be seen that data can follow the existing diagonal line. Therefore, it can be concluded that this research data is normal.

Figure 1: Normality Distribution Test Using P-P Plot

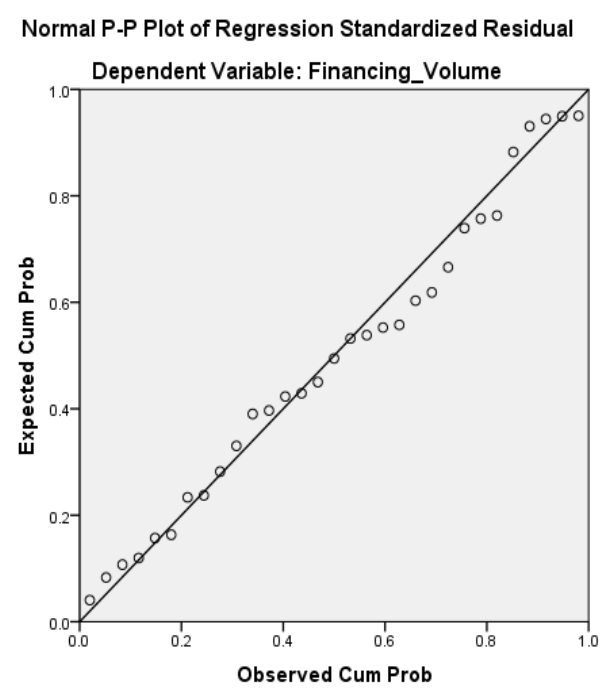

\section{Data Result and Analysis}

On the basis of multivariate regression analysis given in the table 4 , the regression equation is then formulated as $Y=191865,86-0,301 X 1--47,784 X 2+4446,412 X 3-$ $1329839,361 \times 4+1,394 \times 5$ e. The result indicates that loan volume is predicted positively by four independent variables with a significant score of 0.00 . Thus, it can be said that simultaneously the variables of placement with other banks (X1), cash (X2), GRDP (X3), profit sharing financing ratio (X4), and sharia deposit funds (X5) together have an effect on the total volume of financing made by sharia business unit of Bank Sulselbar.

Table 4: Statistical Results of the Determination Coefficient 


\begin{tabular}{|c|c|c|c|c|}
\hline \multicolumn{5}{|c|}{ Model Summary } \\
\hline Model & $\mathrm{R}$ & R Square & Adjusted R Square & Std. Error of the Estimate \\
\hline 1 & $.851^{\mathrm{a}}$ & .725 & .670 & 115630.81368 \\
\hline
\end{tabular}

The determination coefficient parameter as given in table 5 is 0.670 or $67,0 \%$. This means that the four predictors variable explain $67,0 \%$ of the variance and $33 \%$ of the variance cannot be explained the studied variable. It also can be said that variation of the total volume of sharia financing made by sharia business unit of Bank Sulselbar can be explained by variation of placement with other banks (X1), cash (X2), GRDP (X3), profit sharing financing ratio (X4), and sharia deposit funds (X5) is $67 \%$, the rest $33 \%$ is explained by other variables.

Table 5: Statistical Results Using Multivariate Regression Analysis (F-test).

\begin{tabular}{|c|c|c|c|c|c|c|}
\hline \multicolumn{7}{|c|}{ ANOVA } \\
\hline \multicolumn{2}{|c|}{ Model } & Sum of Squares & $\mathrm{df}$ & Mean Square & $\mathrm{F}$ & Sig. \\
\hline \multirow[t]{3}{*}{1} & Regression & 880505102808.169 & 5 & 176101020561.634 & 13.171 & $.000^{\mathrm{b}}$ \\
\hline & Residual & 334262126819.573 & 25 & 13370485072.783 & & \\
\hline & Total & 1214767229627.742 & 30 & & & \\
\hline
\end{tabular}

The partial influence of each variable is examined using t-value. The statistical t-test shows that there are four variables show a significant result of less than 0.05 and one predicted variable show insignificant value. Those four variables are cash $(0.016)$, GRDP (0.044), profit sharing financing ratio (0.045), and deposit funds $(0.00)$. Another predicted variable of placement scores insignificant value of $0,346(0.346>$ 0.05).

The coefficient parameter of variable cash is $-0.47,784$. This means that when the allocation of placement funds increase to 1 unit (1 million rupiah), then the volume of sharia financing will decrease to 47,784 rupiah with assumption other variables unchanged. The coefficient parameter score of the variable GRDP is 4446,412 . It means that when the output of GRDP increase 1 unit (1 billion), the sharia financing volume will increase to 4446, 412 million rupiah with assumption other variables unchanged. With regard to profit sharing financing, the coefficient parameter is 1329839,361. This indicates that when profit sharing from financing activities increased 1 unit, then the total volume of sharia financing will drive down 1329839,361 million rupiah with assumption other variables unchanged. To sharia deposit funds, its coefficient score is 1.394. This means that when sharia deposit funds increase to 1 unit (1 million rupiah), the total volume of sharia financing will increase to 1.394 million rupiah with assumption other variables unchanged.

Viewed from its individual contribution of each variable, standardized coefficient (beta) indicates that deposit funds have a higher impact to the total volume of sharia financing, then followed by cash (-0.373), GRDP (-0.255), profit sharing financing ($0.237)$, and placement $(-0.163)$.

Those four variables are cash (0.016), GRDP (0.044), profit sharing financing ratio (0.045), and deposit funds (0.00). Another predicted variable of placement scores insignificant value of $0,346(0.346>0.05)$. 
Table 6: Statistical Results Using Multivariate Regression Analysis (t-test).

\begin{tabular}{|c|c|c|c|c|c|c|}
\hline \multicolumn{7}{|c|}{ Coefficients } \\
\hline & & \multicolumn{2}{|c|}{ Unstandardized Coefficients } & \multirow{2}{*}{$\begin{array}{c}\text { Standardized } \\
\text { Coefficients } \\
\text { Beta } \\
\end{array}$} & \multirow[b]{2}{*}{$t$} & \multirow[b]{2}{*}{ Sig. } \\
\hline \multicolumn{2}{|c|}{ Model } & $\mathrm{B}$ & Std. Error & & & \\
\hline \multirow[t]{6}{*}{1} & (Constant) & 191865.860 & 108342.670 & & 1.771 & .089 \\
\hline & Placement & -.301 & .314 & -.163 & -.960 & .346 \\
\hline & Cash & -47.784 & 18.539 & -.373 & -2.578 & .016 \\
\hline & GRDP & 4446.412 & 2099.186 & .255 & 2.118 & .044 \\
\hline & Profit_Sharing_Financing & -1329839.361 & 628788.888 & -.237 & -2.115 & .045 \\
\hline & Deposit_Funds & 1.394 & .256 & 1.025 & 5.440 & .000 \\
\hline
\end{tabular}

\section{Discussion and Implication}

On the basis of the statistical result given in table 6 , it can be said that there is a relationship between placement with other banks and the total volume of sharia financing. It is the fact that the more funds placed on the placement account, the fewer funds available that can be used to buffer sharia financing activities. This means that the relationship between placement with other banks and the total volume of sharia financing is negative. This has also been conveyed by a number of researchers who have discovered this relationship.

Similarly, the relationship between cash and the total volume of sharia financing is marked with a negative sign as given in the proposed hypothesis. This is also the same with the statistical result given in Table 6. It is believed that the amount of cash that is placed on the cash account could reduce the availability of funds to support sharia financing activities (Ismail 2011; Hadad et al, 2012; and Mohammad, 2013). It is therefore that when the amount of the funds more put more in cash account, the total amount of sharia financing will be less. This has been said by a number of literature.

GRDP has a positive relationship to the total volume of sharia financing. This can be said that the higher GRDP output will be the higher the total volume of sharia financing. This relationship is very rational because the demand and supply of sharia financing will be more intense in the event of an increase in economic activities. This association has been amplified by Hassan \& Bashir, (2003) and Naifar, (2016).

Profit sharing financing ratio has a positive relationship to the total volume of sharia financing. The increase of profit sharing financing activities from mudharabah and musharakah from previous year could drive effort up to take more financing decisions. Islamic banks will decide to make more financing activities when there is a sign of promising from previous year indicated by profit sharing ratio obtained in the previous year. This profit-sharing relationship has been stated in some literature, in the case of a conventional bank. This condition is found by Sudriman (2013) at Regional Development Bank of Bali (Sudirman, 2013) that found a positive relation of credit performance with profit obtained from previous years.

The relationship between sharia deposit funds and the total volume of sharia financing was found positive. This is in line with findings from other scholars (Pradesyah, 2017). It can be explained that the more funds collected are always 
used as the main buffer for credit activities. This happens not only in conventional banks but also in Islamic banks and sharia business units of regional development banks.

\section{Conclusion}

This study explains the five main variables that can be used to predict the total volume of sharia financing performed by the sharia business unit of Bank Sulselbar. Of the five variables studied, there are four variables showing a significant score, of which two variables have a negative relationship and other two are a positive sign. Variables GRDP and sharia deposit funds have a positive and significant relationship, while the variable profit sharing financing and cash has a negative and significant relationship. Only variable placement has a negative and insignificant relationship. 


\section{REFERENCE}

Abou-El-Sood, H., Abou-El-Sood, H., El-Ansary, O., \& El-Ansary, O. 2017., "Assetliability management in Islamic banks: evidence from emerging markets". Pacific Accounting Review, 29(1), 55-78.

Abduh, M., \& Azmi Omar, M. 2012., "Islamic banking and economic growth: the Indonesian experience". International Journal of Islamic and Middle Eastern Finance and Management, 5 (1), 35-47

Ali, S. S. 2013., "State of liquidity management in Islamic financial institutions". Islamic Economic Studies, 21(1), 63-98.

Alzalabani, A., \& Nair, R. D. 2013., "Financial recession, credit crunch and Islamic banks: a case study of Al Rajhi Bank in the Kingdom of Saudi Arabia". EastWest. Journal of Economics and Business, 2013(1), 15-36.

Ambarwati, S. 2008., "Faktor-faktor yang mempengaruhi pembiayaan murabahah dan mudharabah pada bank umum syariah di indonesia"., (Doctoral dissertation, Universitas Indonesia. Program Pascasarjana).

Andraeny, D. 2011., "Analisis Pengaruh Dana Pihak Ketiga, Tingkat Bagi Hasil, dan Non Performing Financing terhadap Volume Pembiayaan Berbasis Bagi Hasil pada Perbankan Syariah di Indonesia". Simposium Nasional Akuntansi XIV, 47.

Ariff, M. 1988., "Islamic banking"., Asian-Pacific Economic Literature, 2(2), 48-64.

Arshad, N. C., \& Ismail, A. G. 2010., "Shariah parameters for Musharakah Contract: A comment". International Journal of Business and Social Science, 1(1).

Bacha, Ismath O. 2008., "The Islamic interbank money market and a dual banking system: the Malaysian experience. International Journal of Islamic and Middle Eastern Finance and Management, 1(3), 210-226.

Basheer, M. F., Hussain, T., Hussan, S. G., \& Javed, M. 2015., "Impact Of Customer Awareness, Competition And Interest Rate On Growth Of Islamic Banking In Pakistan". International Journal of Scientific \& Technology Research, 4(8), 3340

Burton, M., Nesiba, R., and Lombra, R. 2003.,"An Introduction to Financial Markets and Institutions, (United States, South-Western).

Cahyono, E. F., \& Rani, L. N. 2017., "Performa Efisiensi Teknis Unit Usaha Syariah Bank Pembangunan Daerah Di Pulau Sumatera. Human Falah", (4) 21 - 33.

Dell'Ariccia, G., and Marquez, R., 2003., "Lending Booms and Lending Standards", The Journal of Finance, no 5, 2003, vol 61 2511-2546.

Eickmeier, S., Hofmann, B., and Worms, A., 2008., "Macroeconomic Fluctuations and Bank Lending: Evidence for Germany and the Euro Area, German Economic Review, no 2, 2008, vol 10, 193-223.

Furqaini, N., \& Yaya, R. 2017., "Faktor-faktor yang Mempengaruhi Volume dan Porsi Pembiayaan Berbasis Bagi Hasil Pada Perbankan Syariah di Indonesia". Jurnal F. Ekonomi: JRAK, 7(01).

Ghafar., b. Ismail, A., \& Tohirin, A. 2010., "Islamic law and finance"., Humanomics, 26 (3), 178-199.

Gupta, V. and Jain, P.K., 2004., "Liability Management in Commercial Banks in India: A Comparative Study of Bank Groups in Liberalized-Era", Global Journal of Flexible System Management, no 4, vol 5, 53-66.

Hadad, M. D., Hall, M. J., Kenjegalieva, K. A., Santoso, W., \& Simper, R. 2012., "A new approach to dealing with negative numbers in efficiency analysis: An 
application to the Indonesian banking sector"., Expert Systems with Applications, 39(9), 8212-8219.

Hassan, M. K., \& Bashir, A. H. M. .2003., "Determinants of Islamic banking profitability". In 10th ERF annual conference, Morocco (pp. 16-18).

Hasyim, M. S. 2008., "Bunga Bank: Antara Paradigma Tekstual dan Kontekstual"., HUNAFA: Jurnal Studia Islamika, 5(1), 45-58.

Huda, A. N. 2012., The development of Islamic financing scheme for SMEs in a developing country: The Indonesian case. Procedia-social and behavioral sciences, 52, 179-186.

Ika, S. R., \& Abdullah, N. 2011., "A comparative study of the financial performance of Islamic banks and conventional banks in Indonesia". International Journal of Business and Social Science, 2(15).

Ismal, R. 2011., "Depositors' withdrawal behavior in Islamic banking: the case of Indonesia"., Humanomics, 27(1), 61-76.

Ismal, R. 2009., "Industrial Analysis of Liquidity Risk Management in Islamic Banking". Journal of Islamic Banking and Finance, 26(2).

Kalkarina, S., Rayahu, S., Nurbaiti, A., 2016., "Faktor-Faktor yang Mempengaruhi Pembiayaan Berbasis Bagi Hasil Pada Bank Umum Syariah di Indonesia (Studi Kasus Pada Bank Umum Syariah Yang Terdaftar di BEI)". e-Proceeding of Management : Vol.3, No.3 December 2016, Page 3389 - 3395.

Kamil, K. H., Nilai, B. B., Ismail, A. G., Bangi, B. B., \& Shahimi, S. 2013., "Objectives of Islamic Banks in the Management of Asset and Liability: A Decision Process of Deriving Priority"., Proceedings of the International Symposium on the Analytic Hierarchy Process.

Khan, F. 2010., "How 'Islamic Islamic banking?"., Journal of Economic Behavior \& Organization, 76(3), 805-820.

Kusmiyati, A. N. S. 2007., "Risiko Akad dalam Pembiayaan Murabahah pada BMT di Yogyakarta (dari teori ke terapan)"., La_Riba, 1(1), 27-41.

Juoro, U. 2008., "13 The Development of Islamic Banking in the Post-Crisis Indonesian Economy". Expressing Islam: Religious life and politics in Indonesia, 229.

Masruki, R., Ibrahim, N., Osman, E., \& Wahab, H. A. 2011., "Financial performance of Malaysian founder Islamic banks versus conventional banks". Journal of Business and Policy Research, 6(2), 67-79.

Mawaddah, A., \& Hidayah, N. A. 2012., "Rancang Bangun Sistem Informasi Simpan Pinjam Mudharabah pada Koperasi Baitul Maal Wat Tamwil Ar-Rum”. Studia Informatika: Jurnal Sistem Informasi, 4(2).

Mohammad, S. 2013., "Liquidity Risk Management in Islamic Banks: A Survey. Afro Eurasian Studies"., 1(2), 215-230.

Mokhtar, H. S. A., Abdullah, N., \& Al-Habshi, S. M. 2006, "Efficiency of Islamic banking in Malaysia: A stochastic frontier approach". Journal of Economic Cooperation, 27(2), 37-70.

Muda, M., Shaharuddin, A., \& Embaya, A. 2013., "Comparative analysis of profitability determinants of domestic and foreign Islamic banks in Malaysia". International Journal of Economics and Financial Issues, 3(3), 559.

Naifar, N. 2016., "Do global risk factors and macroeconomic conditions affect global Islamic index dynamics? A quantile regression approach". The Quarterly Review of Economics and Finance, 61, 29-39.

Nandar, B.E., 2010., " Pengaruh Pembiayaan Bank Riau Syariah (BPD Riau) Terhadap Pertumbuhan Ekonomi Provinsi Riau". Skripsi Program Studi 
Muamalat, Fakultas Syariah dan Hukum, Universitas Negeri Syarif Hidayatullah Jakarta.

Nuswantara, B., 2012., "Analisa Penyaluran Kredit Mikro dan Kecil Pada Beberapa Lembaga Keuangan Mikro di Wilayah Jawa Tengah (Analysis of Micro and Small Credits on Microfinance Institutions in Central Java Region), National Conference and Call for Paper of Economic Faculty UNISBANK, Available at http://eprints.unisbank.ac.id/185/1/artikel-23.pdf.

Osmani, N. M., \& Abdullah, M. F. 2010., Musharakah mutanaqisah home financing: A review of literature and practices of Islamic banks in Malaysia. International Review of Business Research Papers, 6 (2), 272-282.

Palupi, I. F. N., \& Kusumawati, E. 2015., "Analisis Pengaruh Dana Pihak Ketiga, Tingkat Bagi Hasil, Non Performing Financing Dan Modal Sendiri Terhadap Volume Pembiayaan Berbasis Bagi Hasil Pada Perbankan Syariah Di Indonesia Studi Kasus Bank Muamalat Indonesia"., (Doctoral dissertation, Universitas Muhammadiyah Surakarta).

Panetto A. R, 1996. "Beberapa Aspek Teori Pengimplementasian Kebijaksanaan Moneter Dalam Pembangunan, Dengan Kasus Indonesia,", Lembaga Penerbitan Universitas Hasanuddin, Makassar, Indonesia, (Lembaga Penerbitan Unhas).

Pato, S. 2013., "Analisis Pemberian Kredit Mikro Pada Bank Syariah Mandiri Cabang Manado". Jurnal Riset Ekonomi, Manajemen, Bisnis dan Akuntansi., 1(4).

Pradesyah, R. 2017., Analisis Pengaruh Non Performing Loan, Dana Pihak Ketiga, Terhadap Pembiayaan Akad Mudharabah di Bank Syariah. Intiqad: Jurnal Agama dan Pendidikan Islam, 9 (1).

Pratami, W. A. N., \& Muharam, H. 2011., "Analisis Pengaruh Dana Pihak Ketiga (Dpk), Capital Adequacy Ratio (Car), Non Performing Financing (Npf) Dan Return On Asset (Roa) Terhadap Pembiayaan Pada Perbankan Syariah (Studi Kasus Pada Bank Muamalat Indonesia Periode 2001-2011)"., (Doctoral dissertation, Universitas Diponegoro).

Puspitasari \& Ellen. 2017., "Analisa Faktor-Faktor yang Mempengaruhi Pembiayaan Berbasis Bagi Hasil pada Bank Umum Syariah di Indonesia Tahun 20102015"., Students' Journal of Accounting and Banking, 6(1).

Rejeki, F. Y. S. 2013., "Akad Pembiayaan Murabahah dan Praktiknya Pada PT Bank Syariah Mandiri Cabang Manado. Lex P rivatum, 1(2).

Seibel, H. D. 2008., "Islamic microfinance in Indonesia: The challenge of institutional diversity, regulation, and supervision". SOJOURN: Journal of Social Issues in Southeast Asia, 23(1), 86-103.

Setiawan, C., \& Putri, M. E. 2013., "Non-performing financing and bank efficiency of Islamic banks in Indonesia". Journal of Islamic finance and business research, 2(1), 58-76.

Singkey, Josepth F., 1998., "Commercial Bank Financial Management", $5^{\text {th }}$ Edition, United State of America, Prentice-Hall, Inc. Publishing.

Sudirman, I. W., 2003., "Faktor-Faktor Penghambat Peningkatan Loan to Deposit Ratio (LDR) Perbankan di Provinsi Bali”, Journal of Indonesian Economy and Business, $\mathrm{p}$ (nd).

Suhendi, H., \& Si, M. 2002., "Fiqh Muamalah Membahas Ekonomi Islam Keududukan Harta, Hak Milik, Jual Beli, Bunga Bank dan Riba, Musharakah, ljarah, Musayanah, Koperasi, Auransi, Etika Bisnis dan lain-lain". 
Sun, P. H., Hassan, M. K., Hassan, T., \& Ramadilli, S. M. 2014., "The assets and liabilities gap management of conventional and Islamic banks in the organization of Islamic Cooperation (OIC) countries". Applied Financial Economics, 24(5), 333-346.

Susilo, S., Hubeis, M., \& Purwanto, B. 2012., "Pengaruh Karakteristik dan Perilaku UKM, serta Sistem Pembiayaan terhadap Penyaluran Pembiayaan BNI Syariah". MANAJEMEN IKM: Jurnal Manajemen Pengembangan Industri Kecil Menengah, 7(1), 1-9.

Usmani, M. T. 1999., "The concept of musharakah and its application as an Islamic method of financing". Arab Law Quarterly, 14(3), 203-220.

Zaher, T. S., \& Kabir Hassan, M. 2001., "A comparative literature survey of Islamic finance and banking". Financial Markets, Institutions \& Instruments, 10(4), 155199. 